\title{
RADNIČKO KNJIŽEVNO STVARALAŠTVO U SAMOUPRAVLJANJU: REPRODUKCIJE KANONA, KNJIŽEVNOST I PRAKSE SVAKODNEVICE

\section{BORIS KOROMAN}

Odsjek za kroatistiku, Filozofski fakultet

Sveučilišta Jurja Dobrile u Puli

U radu ${ }^{1}$ se pristupa korpusu od stotinjak pjesama različitih autora, nastalom i objavljivanom u tzv. radničkoj periodici, tvorničkim novinama koje su postojale u jugoslavenskom samoupravnom socijalizmu u vremenu od 1947. do 1990. U novinama i biltenima poduzeća iz Istre - Raški rudar: glasilo Istarskih ugljenokopa "Tupljak", Uljanik: mjesečnik SOUR-a Brodograđevna industrija Uljanik, Pula, Naš glas: glasilo poduzeća Rivijera Poreč, Anita: list hotelsko turističkog poduzeća "Anita", Glasnik Plave lagune: list Plave lagune Poreč, Porečki glasnik: glasilo SSRN i udruženog rada Poreštine - povremeno su bile objavljivane i pjesme radnica i radnika, a Brodogradilište "Uljanik" pritom je imalo i aktivnu književnu sekciju. Na prvoj razini građi se nastoji pristupiti motivskom, tematskom i stilskom analizom da bi se potom otvorila interpretativna pitanja koja proizlaze iz pojedinih podudarnosti u postupcima proizvodnje teksta. Interpretiraju se stilsko-tematska čvorišta u lirici na čakavskom, zatim u primjerima refleksivne i ljubavne poezije te u pjesmama koje tematiziraju rad, radno mjesto te žanrom satire kritički upućuju na osjetljiva mjesta samoupravne radničke svakodnevice.

Ključne riječi: samoupravljanje, radnička umjetnost, radnička poezija

' Ovaj rad nastao je u okviru projekta "Stvaranje socijalističkoga čovjeka. Hrvatsko društvo i ideologija jugoslavenskoga socijalizma” (1718), financiranog sredstvima Hrvatske zaklade za znanost. 


\section{UVOD: KULTURA I SAMOUPRAVLJANJE}

Pitanje kulture $u$ jugoslavenskom socijalizmu, a posebice $u$ okviru teorije, prakse i logike njegove specifične sastavnice - samoupravljanja - kompleksno je i zahtijeva iscrpna istraživanja uz korištenje različitih teorijskih aparata. Problemom toga odnosa bavio sam se i u radu "Radnički tisak i problemi koncepta samoupravljanja u kulturi u Hrvatskoj 70-ih i 80 -ih godina 20. st." (Koroman 2016). Ovaj se rad nadovezuje na to istraživanje izdvajajući iz te građe nove elemente za analizu radničke umjetničke literarne prakse, pritom drugačije postavljajući interpretativne aparate.

Budući da je već kultura "multidiskurzivan" pojam (Hartley u Duda 2002: 9), a samoupravljanje široko postavljena ustavna vrijednost socijalističkog društva, međuodnos tih dvaju termina naviješta nestabilnost i izazov. ${ }^{2}$ Povijest artikuliranja njihove povezanosti, odnosno pokušaja uspostavljanja njihove veze u onome što bi se, posebice od 1970-ih, moglo nazvati "kultura samoupravljanja", "kultura u samoupravljanju”, ili "samoupravljanje u kulturi" (premda se ne radi o istoznačnicama) može se pratiti od samog osmišljavanja relativno autentične marksističke politike samoupravljanja, još od njezina začetka u kasnim četrdesetim godinama 20. stoljeća. U temeljnoj političkoj literaturi koja je kroz četiri desetljeća pratila taj projekt (npr. Kardelj 1977; Horvat 1983) kultura se spominje sporadično kao usputna i logična nadgradnja postavljenih političko-ideoloških temelja društva. I recentne studije o samoupravljanju, poput one Darka Suvina Samo jednom se ljubi: radiografija SFR Jugoslavije (2014), efemerno se dotiču kulture i kulturnih politika.

Različite smjerove artikuliranja kulturnih politika u socijalističkoj Jugoslaviji od njezine uspostave pa do kraja tog društvenog sustava početkom devedesetih moguće je opisati i razaznati, no zapravo je riječ o nekoherentnim, heterogenim, katkada i inovativnim te svakako multicentričnim procesima, koji se prepliću kroz desetljeća kulturnih praksi. Od šezdesetih godina, zbog daljnjeg razvoja koncepta samoupravljanja, postupno se odustaje od "klasičnog administrativno-etatističkog" modela kulturne politike, koji u svojoj studiji o kulturnoj politici Jugoslavije do šezdesetih godina opisuje Branka Doknić (2013). Taj se model razvija u onaj koji uključuje složen odnos ustavne kategorije samoupravljanja i kulture.

Kada je riječ o samoupravljanju, čvrstoj točki prakse jugoslavenskog socijalizma, i pokušajima njegova artikuliranja u polju kulture, tek se određene značajne smjernice - ne bez dosta prijepora, pa i proturječja, te katkad gotovo i naivnog idealizma - mogu iščitavati u nizu eseja koje ispisuje i objavljuje u knjizi Politika i kultura najetabliraniji ideolog partijske kulture u samoupravljanju, Stipe Šuvar (1980). Polazeći od revolucionarnog nultog vreme-

2 Samoupravljanje se, dakako, uvodi postupno u jugoslavensko društvo i neprestano nadograđuje, od ideje prvih radničkih savjeta, oko 1949. (usp. Stanić 2014: 454), do njegova ustoličenja na najvišim pravnim razinama, u ustavima iz 1963. i 1974. Posebno se uz ustav iz 1974. vezuje nastanak samoupravnih interesnih zajednica (SIZ), nakon čega su SIZ-ovi za kulturu postali nova instanca promišljanja politika kulture u samoupravljanju. 
na proizvodnje novog društva i novog socijalističkog čovjeka, od razdoblja stvaralaštva u razdoblju Narodnooslobodilačke borbe u Drugom svjetskom ratu, Šuvar postavlja neke od okvira za promišljanje koncepta kulture u samoupravljanju. Riječ je o obliku narodne kulture, no ne u folklornom "epsko-pastirskom" smislu, već o kulturi stvorenoj povijesnim procesima uzdizanja do razina "nove društvene svijesti", onoj koja je "ovladala većinom naroda" te se tako "plebejskim stvaralaštvom" dogodila "sinteza umjetnosti i revolucije" (Šuvar 1980: 95). Također, Šuvar se u tim esejima izričito ograđuje, pa i obračunava s "buržoaskim" konceptima elitne kulture, zagovarajući demokratičan i svedostupan model kulture, koji nastaje u "historijskom procesu demokratizacije kulture" (isto: 106) te kojem upravo amaterizam postaje referentno mjesto i polje upisivanja samoupravnih vrijednosti. Problem s tako uskim konceptom je njegovo negativno određenje; zamišljena kultura u samoupravljanju određuje se nasuprot folklornoj, retrogradno tradicionalističkoj, buržoaskoj, isključivo klasnoj (npr. radničkoj) kulturi te, u svakom slučaju, nasuprot različitim nacionalističkim artikulacijama kulture (isto).

Okviri nacrta odnosa kulture i samoupravljanja, od onih koje su vrlo općenito postavili primjerice Kardelj i Bakarić pa do specifičnih Šuvarovih, otkrivaju demokratičnu nakanu političkih struktura da se, idejno sasvim na marksističkoj liniji, "dostupnošću sredstava za proizvodnju" i propulzivnošću vertikale visokih i niskih modusa umjetnosti, a koji obilježavaju modernističko artikuliranje pojma umjetnosti, umjetnost kao praksa dehijerarhizira. Iznimno je zanimljivo promatrati kako je kultura, "samoupravna kultura", odnosno kultura u okviru samoupravljanja u toj nakani definirana zapravo prilično suvremeno i podudarno zapadnjačkim promišljanjima marksističke provenijencije, primjerice kod Raymonda Williamsa (1965) ili Paula Willisa (2006), koji također upućuju na njezinu "običnost" i "svakodnevnost". Baš kao i zapadni mislioci ljevice i Stipe Šuvar dolazi do ove definicije: "Kultura u najširem smislu je način života" (Šuvar 1980: 15., usp. i isto: 179). Ta je podudarnost teza o "običnosti" kulture ovdje postavljena tek kao metonimija jer je na značajnije veze i otvorena pitanja koja dotiču problem marksističkih artikulacija kulture, probleme prakse i analitičke izazove koji se otvaraju kada se kultura ostvaruje upravo "u uvjetima vladavine ljevice" upozorila u kritici koja izlazi isključivo iz okvira samoupravnog socijalizma Reana Senjković u knjizi Izgubljeno u prijenosu: pop iskustvo soc kulture (2008).

U radu "Radnički tisak i problemi koncepta samoupravljanja u kulturi u Hrvatskoj 70-ih i 80-ih godina 20. st." (2016) obrađivao sam na građi radničke periodike, koju koristim i u ovome radu, na koji se način pojam kulture artikulira u tom mediju namijenjenom radnicima u poduzećima, kako se kulturne politike i partijske rezolucije o kulturi pojašnjavaju i prenose "bazi”, kako se pritom pokušava konstituirati "kultura u samoupravljanju", na koji način, kroz dostupne intervjue s radnicima u periodici, oni sami razumiju pojam kulture te, konačno, što imaju reći o modelu radničke participacije u SIZ-ovima za kulturu. Ti prijepori, uz nedostatak konzistentnih kulturnih politika u razdoblju jugoslavenskog samoupravljanja te uz "neuspjeh prakse" koncepta "kulture u samoupravljanju" (Koroman 2016: 632, 633), motivacija su za istraživanje konkretnih radničkih umjetničkih praksi proizašlih iz tog modela. 


\section{GRAĐA: RADNICI I RADNICE I NJIHOVO KNJIŽEVNO STVARALAŠTVO}

U ovome radu istraživanje se odnosi na konkretnu građu koja nastaje kao umjetnička praksa u kontekstu samoupravljanja, radničko amatersko književno pjesničko stvaralaštvo koje se objavljuje u časopisima i novinama poduzeća. Istraživanje je provedeno na sedam istarskih tiskovina koje mogu biti reprezentativne za različite sektore privrede. Periodiku iz privrednih grana industrije predstavljaju Raški rudar: glasilo Istarskih ugljenokopa “Tupljak”, Labin (1947. - 1993.) i Uljanik: mjesečnik SOUR-a Brodograđevna industrija Uljanik, Pula (1980. - 1991.). Raški rudar najznačajnija je tiskovina koja je izlazila od samog početka radničkog tiska u socijalističkoj Jugoslaviji, dok je Uljanik, nakon velikog prekida, 1980. ${ }^{3}$ godine ponovo ambiciozno pokrenuo objavljivanje svog moderno osmišljenog časopisa. Analizirani časopisi iz Poreča i okolice, redom bilteni radnih organizacija koje se bave turizmom, pokrivaju tercijarni sektor usluga: Naš glas: glasilo poduzeća Rivijera Poreč, Poreč (1968. - 1982.), Anita: list hotelsko turističkog poduzeća “Anita”, Vrsar (1970. - 1982.) i Glasnik Plave lagune: list Plave lagune Poreč (1970. - 1982.). Te se tiskovine 1982. godine udružuju u tjednik Adria: list udružene privrede Poreštine (1982.), koji je 1983. godine prerastao u utjecajni lokalni tjednik Porečki glasnik: glasilo SSRN i udruženog rada Poreštine (1983. - 1994.). Urednička i novinarska ekipa iz Našeg glasa preuzima u različitim funkcijama i Adriv i Porečki glasnik te se podudarnosti u koncepcijama uredničkih politika, kao i autorski rukopisi i pojedina rješenja mogu prepoznati u više različitih tiskovina. $U$ radu se prati i analizira građa od početaka objavljivanja navedenih tiskovina do 1991. godine.

Ideja povremenog praćenja i objavljivanja poezije koju pišu sami radnici iz pogona ili drugih sastavnica poduzeća zajednička je svim analiziranim časopisima. Naglasak je na "povremenosti"; tjednici ili mjesečnici uglavnom nemaju stalnu rubriku radničkog stvaralaštva i pjesme se tek katkad objavljuju u posebnim prilozima koji zaživljuju neko vrijeme ("Iz rada literarne sekcije", "Poetski kutak" i sl.). Čak se i u medijima poduzeća organizirani kulturni amaterizam prati sporadično i puno rjeđe u odnosu na primjerice amaterski sport i rekreaciju, a tek oni bolje organizirani i veći pogoni, poput Uljanika, imaju i aktivnu književnu sekciju.

Časopisi i novine tvornica i poduzeća pojavljuju se 1947. godine kao svojevrstan nastavak kulturno-prosvjetnih djelatnosti koje u neposrednim poslijeratnim godinama provode sindikati (JRSS), zatim tradicije različitih radničkih i lijevih stranačkih tiskovina u među-

\footnotetext{
3 Uljanik: glasilo Radne organizacije "Uljanik" - Brodogradilišta i tvornice dizel motora Pula u sastavu združenog poduzeća "Jadranbrod" izlazi od 1954. do 1968., međutim u tom razdoblju predstavlja novinu namijenjenu distribuciji informacija koje se tiču poslovanja i organizacije tog velikog poduzeća. Godine 1974. osnivaju se u Brodogradilištu "Uljanik" različite umjetničke sekcije pri Kulturno-umjetničkom društvu "Uljanik", pa tako i literarna, nakon čega se može pratiti i književni rad radnika i radnica brodogradilišta. Obnovljena edicija biltena Uljanik pokrenuta je krajem 1980. godine te se radničko stvaralaštvo tog poduzeća, kroz časopis i dvije zbirke literarne sekcije, u ovome radu prati od tog vremena.
} 
ratnom periodu te kao logičan razvoj prakse industrijskih "zidnih novina", što je poticala Kominterna (usp. Koroman 2016). Te su novine objavljivala sama poduzeća i tvornice, publiku su im činili radnice i radnici, zatim članovi njihovih obitelji, a distribuirale su se besplatno unutar pogona.

Kroz nadolazeća desetljeća pojedini radnički časopisi i novine profiliraju se kao informativna glasila tvrtki, medij kojim se diseminiraju informacije važne za radnike. Radnička periodika medij je koji je komunikacijski složeno kodiran. S jedne strane, tiskovine se koriste za reprodukciju ideoloških sadržaja, što je posebno vidljivo u razdoblju rezolucije Informbiroa četrdesetih godina, a kasnije posebno kroz različite obavezne "obljetničke" sadržaje. S druge strane, to je osnovni informativni medij za radnike, u kojem se piše o proizvodnim procesima, uspjesima i problemima, upravljanju, legislativi, posebno uz tumačenja radnih zakona i pravilnika te o temama vezanim uz socijalnu ili stambenu politiku u poduzeću. $S$ proširenjem tema na putopisne reportaže, kulturnu ponudu, turizam, savjete o zdravlju ili stanovanju, 1960-ih se godina neke od tih novina, posebno Raški rudar i novine poduzeća u turizmu, profiliraju kao tiskovine namijenjene i obiteljima radnika. To je medij u kojem se od samog početka, barem deklarativno, inzistira na dvosmjernoj komunikaciji i "davanju glasa radnicima". Karakteristično je također da gotovo svaka od tih tiskovina ima prostor za tzv. "lakše teme", razonodu, enigmatiku, humoristične priloge, a u tom dijelu novina objavljuju se i radnička umjetnička djela, ponajviše poezija i karikature.

Ukupno, ta građa nije opsežna, riječ je tek o stotinjak pjesama objavljenih u tvorničkim tiskovinama te još stotinjak iz dviju zbirki koje je objavila Literarna sekcija brodogradilišta Uljanik. Činjenica koja, međutim, privlači analitičku pozornost iz pozicija povijesti kulture, istraživanja socijalizma te povijesti književnosti jest ta da ta građa mahom nije očekivano raznolika. Kod vrlo različitih autora, iz različitih socijalnih okruženja, različitih profesija, sociokulturnog kapitala, generacija, podrijetla i spola, nastaje poezija u kojoj se mogu razaznati podudarnosti, motivske i tematske, poetičke izvedbene sličnosti, komplementarne linije utjecaja, ili problemski neksusi. Iz toga se zapažanja nameće pitanje koje traži analitički odgovor: zašto literarno stvaralaštvo u samoupravljanju izgleda upravo tako?

Radnička periodika u posljednjih je nekoliko godina u fokusu dijela istraživača povijesti jugoslavenskog socijalizma. Svi tekstovi u tom mediju nastaju u relativno samostalnim samoupravnim jedinicama, "radnim organizacijama" i u specifičnim radnim okolinama. Intervjui s radnicima, članovima uprave ili političkih tijela $u$ tim se medijima bave realnim problemima na terenu, u kontekstu koji je dobro poznat svim akterima medijske komunikacije. Stoga i ne čudi da posljednjih godina publikacije proizvodnih organizacija namijenjene radnicima zaokupljaju pažnju istraživača primjerice $u$ istraživanjima studija slučaja promjene paradigme radničkih prava u poduzeću Borovo (Cvek, Ivčić i Račić 2015) ili samoupravljačkih procesa u Uljaniku (Stanić 2014). U svim tim istraživanjima ta se građa pokazuje kao poseban i iznimno bogat izvor informacija, no pojava poetskog stvaralaštva radnika u (samoupravnom) socijalizmu u novije vrijeme nije istraživana. 


\section{PRISTUPI GRAĐI}

U ovom se tekstu analiziraju pjesnički radovi objavljeni u radničkom tisku, dok su zbirke poezije literarnih klubova spomenute kao ilustracija i dopuna. Nekoliko je razloga zašto se amatersko stvaralaštvo u kulturno-umjetničkim sekcijama postavlja u drugi plan. Ponajprije, riječ je o tome što bi tema književnog amaterizma mogla biti značajnom komparativnom temom istraživanja većeg opsega. Nadalje, ta se poezija objavljuje u vrlo specifičnom kontekstu u radničkim novinama, okružena vijestima i člancima koji su sigurno od velikog interesa većini radnika; ciljana publika je, stoga, drugačija i šira od publike pjesničkih zbirki te je vjerojatno da urednički izbor pjesama u radničkim novinama omogućuje da je ta poezija doista i čitana, da ima očekivano relativno dobru recepciju. Također, a vezano uz kontekst i uređivačke politike o člancima koji su korisni radnicima, radnici-književni stvaraoci su ponekad predstavljeni i kratkim uvodom, koji je također dio teksta iz kojeg se mogu iščitati međusobni odnosi sustava samoupravljanja i pojedinačnih umjetničkih iskaza.

Iznimno je složeno pitanje analitički primjerenog i korisnog pristupa tim tekstovima. Uobičajen i logičan način na koji se može pristupiti toj građi je da je se promatra kao praksu kulturnog amaterizma, no na toj se očiglednoj poziciji nije uputno jednostavno zaustaviti. Kulturni amaterizam otvara i nekoliko drugih problema: najprije, on nije participativna praksa koja nužno mora biti povezana s konceptima marksizma ili uopće lijevih kulturnih politika ili pak, konkretno, samoupravljanja. S druge strane, "plebejsko stvaralaštvo", odnosno revolucionarni kulturni amaterizam, kakvoga u konceptima kulturnih politika zagovara Stipe Šuvar (1980), može se odvijati samo u prevratnim povijesnim okolnostima. U postrevolucionarnim okolnostima u kojima valja konstituirati (novo) društvo, ono u kojem "prošlost postaje sve manje relevantna kao prethodeći model za većinu oblika ljudskog ponašanja" (Hobsbawm 1983: 11), kulturni amaterizam, njegove prakse i umjetničke objave doista bi se mogle prepoznavati kao primjeri "invencije tradicije" s pripadajućom konstelacijom kanona u neprestanoj (novo)gradnji.

Uza sve teorijsko iskustvo dvadesetog stoljeća, “beskonačnost teorije” (Culler 2001: 24) i “demone teorije" (Compagnon 2007), književna povijest ostaje disciplinom čije se epistemološke, metodološke, pedagoške i političke osnove i danas, kao i u razdoblju socijalizma, određuju koordinatama nastalim u razdoblju moderniteta. Drugim riječima, i pored toga što se "književnopovijesno istraživanje održava otvorenim i plodnim upravo zbog toga što se jaz između onoga što funkcionira kao da je njegov referent (tj. svih razvedenih oblika tvorbe ukupne predodžbe o književnosti) i referenta toga referenta (tj. "književnosti same') - nikad ne zatvara" (Biti 2000: 416), povijest književnosti i dalje se dominantno određuje koncepcijama "duhovne povijesti" ili "kulturnog identiteta" i "zajedničkim kulturnim krugovima” (usp. Solar 2006: 229). Takav postav pretpostavlja svojevrsna kritička ekspertna vrednovanja tekstova uz određivanje i procjenjivanje njihove literarnosti te $u$ slučaju korpusa tekstova koji su predmetom analize u ovome radu može se pokazati "korisnim" isključivo kroz prizmu detektiranja referencijalnih koordinatnih točaka, literarnog ili "lektirnog" kanona te potom njegove reprodukcije ili specifičnih otklona. 
Analiza koja polazi iz tradicija marksizma i neomarksizma ukazuje nadalje na probleme u artikulaciji kulture unutar te paradigme, uključujući i problem odnosa kulture i klase sl. Takva analiza svakako uzima u obzir i različite interpretacije književnosti u marksističkim paradigmama, međutim, tu se otkriva i granica epistemološkog okvira marksističkih teorija; poezija koja nastaje u kulturno-umjetničkim amaterskim književnim društvima ili klubovima u poduzećima nastaje upravo u ostvarenim uvjetima kakve je zapadna marksistička misao teorijski zamišljala, odnosno "u uvjetima vladavine ljevice" (Senjković 2008). S time je u velikoj mjeri i "potrošena", ublažena ili barem dovedena pred kriterij prakse važna značajka njezine oporbenosti ili revolucionarnosti, kao kategorija koje u umjetnost upisuju (modernistički) utopizam ili potencijal društvenog napretka. U uvjetima kada je samoupravljanje temeljni okvir izgradnje društva, ta bi građa, gotovo neautorski ili anonimno prezentna u medijima namijenjenim upravo drugovima iz poduzeća, trebala predstavljati konkretno oprimjerenje tog teorijsko-praktičkog prijepora.

Svi marksistički teorijski pristupi umjetnosti polaze od ideje dostupnosti "sredstava za proizvodnju" svima, tako i u području kulture, sve od ranih Engelsovih, preko Williamsovih (1977) pa i do Enzensbergovih radova (1970), koji katkad ponešto samokritički prepoznaje problem u slabosti, ili čak nemogućnosti artikulacije marksističke teorije medija. Problem, konceptualan i realitetan, koji proizlazi iz građe, a koji je u vezi s tezom Reane Senjković, jest u tome što takva ideja, u jugoslavenskom društvu dosljedno provedena i osnažena jasnom politikom, u odrazima svakodnevice nudi građu koja se doima neizazovnom ili banalnom, baš kao što se i Šuvar "u svome traženju dobroga puta za kulturu u socijalizmu nije dosjetio mnogo toga novoga" (2008: 39).

Problem nalaženja odgovarajuće forme nazire se i unutar kompleksne pojave partizanske umjetnosti u NOB-u, nultoj točki "preokreta", koja će se prepoznati kao "istinska kulturna revolucija" (Šuvar 1980: 94), umjetnost u "rudimentarnim artističkim shemama” (isto: 95). Na liniji promišljanja te umjetnosti kao prijeloma i napetosti između "još-ne-realiziranog" i otvaranja "prostora za još-ne postojeće" (Komelj 2012: 7) je i recentna analiza fenomena partizanske umjetnosti Miklavža Komelja Kako misliti partizansko umetnost?. No i u toj se knjizi analizirano stvaralaštvo poznatih, ali i brojnih anonimnih autora i autorica uokviruje povijesnim kontekstom Drugog svjetskog rata. "Ireverzibilnost prijeloma", posljednje poglavlje knjige, upućuje na element nužnosti djelovanja, stvaranja "u trenutku” (isto: 495), no ta umjetnička, utopijska, poetička i politička maksima ne predviđa procese u kojima se taj trenutak pretvara u značajan element organizacije društva, s jasnom političkom okosnicom i hegemonijskim učincima. ${ }^{4}$

Konačno, i Bourdieova "društvena kritika suđenja" (2011) samo priprema teren za otvaranje problema: nastala kao opsežna analiza klasa i kultura u francuskom društvu koje u

${ }^{4}$ Pojedini teoretičari koji naginju polu kritike marksizma tražeći mjesta u "postmarksističkim" potezima, poput Lavellea primjerice, primjećuju i u čitavim poglavljima upućuju na problem u određenju pojma "književnost radničke klase" (Lavelle 2012), odnosno problem estetike te uspostavljanje "diskursa" o književnosti radničke klase, koji je "zaštićen od vanjskih izazova" i koji "ne može sebe preispitivati" (isto: 100). 
to doba još uvijek gotovo potpuno pripada modernosti, svojim koordinatama za moguće analize jugoslavenskog društva određenog samoupravljanjem može tek dijelom potvrditi teze i o njegovoj modernosti i o pokušajima propitkivanja klasnih razlika, a s druge strane u analitičkom susretu s praksom ekspandirati u pitanjima o "ukusu", "sociokulturnom kapitalu”, "malograđanskom ukusu” u tom kontekstu.

Tradicija proučavanja pučke književnosti, još od vremena socijalističke Jugoslavije (npr. Bošković-Stulli i Zečević 1978), ili "paraliterature”, odnosno “divlje književnosti” (Čolović 1985), ponudila je mogućnost klasifikacije i provođenja kroz deskripciju ili historiografiju (primjerice u različitim monografijama o amaterizmu) raznih rubnih oblika ili međuoblika umjetničkog izražavanja. Zanimljiv recentniji prilog ponudio je u knjizi Everiday Genius sociolog Gary Alan Fine (2004). Polazeći od sličnih pitanja u pretežito etnografskom istraživanju, u kojem simptomatično primjećuje izostanak kazivača srednje klase, Fine podsjeća i na terminološku zbrku, pa i politički obilježene nazive tog tipa umjetnosti: primitive, naive art, folk art, outsider art, vernacular art, boundary art, opredjeljujući se za neutralno self-taught art (isto: 3-4).

$U$ istraživanju poezije radnika i radnica metodologiju bi trebao oblikovati, barem u jednoj sferi, pokušaj traženja odgovora na istraživačka pitanja koja se postavljaju kada se čitatelj nađe pred radničkom poezijom, upoznat s nekima od sastavnica samoupravnog socijalističkog sustava: po čemu je ta poezija specifična? Koja se praksa, koji svijet, potencijal, koja vrsta tekstualnosti ili skripture može prepoznati iza naizgled katkada i nesklapnih ili konvencionalnih stihova?

Jednostavan model motivskih i tematskih podudarnosti i okupljanja te njihova analiza svakako je prva postaja ovoga pristupa; već se na toj razini mogu uočiti i reprodukcije kanona i specifičnosti građe. Reprodukcija kanonskih tema, osobito regionalne i lokalne artikulacije književnosti i specifičnosti proizvodnje tekstova, zahtijevaju tako i interpretacijske poteze iz širokog spektra kulturalne teorije. Specifičnosti se pak na toj motivsko-tematskoj razini uočavaju u angažiranoj književnosti, pjesmama koje se katkad odnose na vrlo uzak i specifičan kontekst artikulacija samoupravnih odnosa u pojedinoj tvrtki ili općenitih problema sustava.

Na drugoj razini, navedenim se pitanjima može pristupiti iz pozicije pripitomljavanja jezika i "prizemljivanja" pojmova jezika, književnosti i kulture, njihovog "skidanja" s visina modernističkog "aristokratizma duha" i politika koje promiču dostupnost (nekadašnje) tzv. "visoke" ili "elitne" kulture, kao i pripadajućih "sredstava za proizvodnju” kulture. Pritom, spomenute teze o "običnosti" kulture, koje se reproduciraju i u zapadnim kulturalnostudijskim zamišljanjima kulture, od Raymonda Williamsa naovamo, također su konstanta i konstituenta promišljanja kulture u samoupravljanju. Pomak k "običnosti" kulture može tako otvoriti i teorijsku razradu kakvu je ponudio de Certeau u Invenciji svakodnevice (2002). Michel de Certeau bavi se praksama svakodnevice i složenim odnosom kultura odozgo i aktivnih primatelja iz raznih podređenih pozicija, pregovarača i proizvođača uglavnom lišenih političke moći te je njegov integrativan pristup jedna od mogućih pozicija s koje se može pristupiti kulturi i književnosti u samoupravljanju. 


\section{ČAKAVSKA LIRIKA OD KAMPANILIZMA DO SVAKODNEVICE}

U analizi naglasak je na tekstovima pjesama: građa se u motivsko-tematskoj istraživačkoj poziciji uzima kao nulta točka analize te se svjesno izbjegava upućivanje na konkretno autorstvo. Ono je, međutim, spomenuto i, dapače, naglašeno u svim primjerima u kojima ima interpretacijski značaj.

Prvu tematsko-stilsku skupinu pjesama vrlo se lako može obuhvatiti i prepoznati kao poeziju regionalnog čakavskog izričaja, te su dio autora koji se pojavljuju u toj građi pisci koji su zastupljeni i u antologijama čakavske poezije (usp. Biletić 1997). ${ }^{5}$ Motivski neksusi većinom obuhvaćaju repertoar kampanilizma, rodno mjesto (npr. Višnjan spi (NG 15. 5. 1981.: 10)), seoski ambijent (Speštano hižišće (ULJ 8. 3. 1990.: 34), Par voli (NG 15. 2. 1981.: 10)), odnosno motive u kojima se tematizira prošlost u različitim verzijama tipičnih negativnih "idealizacija”, pretežno siromaštva (Nikada (ULJ 8. 3. 1990.: 34), Zaresle su staze AN 26. 12. 1977:: 10, Naši stari NG 15. 11. 1980.: 4)). Česti su i motivi majke (npr. Mati i Pismo materi (ULJ 8. 3. 1990.: 29)), kao dio utjecaja Mate Balote, premda je općenito u toj građi motiv majke katkad prigodno povezan s obilježavanjem Međunarodnog dana žena (npr. NG 15. 3. 1981.: 8). Nasuprot tome, poseban tip čakavskih pjesama o ženama usmjeren je negativnoj i banalnoj stereotipizaciji, posebno mladih ili modernih žena (kao potrošačica ili sumnjiva poštenja (npr. ULJ 4. 4. 1984.: 25)). Ako bismo ih pokušali povezati s nekim usmenim folklornim žanrovima najsličnije bi bile rugalicama, a simptomatično je da ih ispisuju radnici muškarci, što otvara prostor za teme promišljanja rodnih odnosa u socijalističkoj Jugoslaviji i u razdoblju kasnog socijalizma, ${ }^{6}$ a specifično lokalnije, i za reprodukcije patrijarhalnih silnica u Istri.

Uz majku, i ostali obiteljski i generacijski motivi uobičajen su dio tog patrijarhalnog repertoara, primjerice Tri brata (ULJ 8. 3. 1990.: 29). Dio repertoara uklapa lokalnu regionalnu motiviku u šira iskustva mediteranizma, primjerice pjesme Vino (NG 15. 7. 1981.: 10) i Martinja (ULJ 8. 3. 1990.: 29), te se u tom tipu izričaja može prepoznati i svojevrsni pomak od kampanilizma prema hedonizmu svakodnevice.

U vezi sa skretanjem prema "lakšem" i opuštenijem izričaju, mogu se pronaći i drugačija motivsko-tematska čvorišta. Primjerice, u pjesmi Špeža (NG 15. 3. 1981.: 10) tematizira se svakodnevna kupovina, Moj zrman Merikan (ULJ 15. 4. 1981.: 33) opisuje doživljaje jednog Rakljanina u Americi, dok je pjesma Litnja manovra na moru (NG 15. 7. 1981.: 10) duhovita anegdota o nespretnim turistima. Premda posljednju pjesmu valja promatrati i u kontekstu njezina objavljivanja, a to je časopis tvrtke koja se bavi turizmom, ona se zapravo tipom uklapa u povijesnu liniju čakavske poezije, koja u osamdesetim godinama, posebno sa

\footnotetext{
${ }^{5}$ Riječ je o pjesnicima kao što su Janko Crljenica, Denis Kontošić, Dinko Š. Kalac, koji rade u brodogradilištu Uljanik. U građi se u Našem glasu pojavljuju i pjesme Tomislava Milohanića, ekonomista po struci i također danas renomiranog čakavskog pjesnika.

${ }^{6}$ Upravo se rodnim odnosima u pogonima u socijalističkoj Jugoslaviji bavi Chiara Bonfilioli u nizu istraživanja o tekstilnim radnicama (usp. Bonfiglioli 2015).
} 
zbirkama novinara i kulturnog radnika Drage Orlića, neko vrijeme i urednika Našeg glasa, postaje afirmiranim pjesničkim idiomom u kojem se tematika svakodnevice i hedonizma, uz mnogo humora, pojavljuje kao prepoznatljiva značajka čakavske poezije.

Uz čakavsku poeziju valja spomenuti i, doduše vrlo sporadične, priloge lokalnih pjesnika na talijanskom jeziku, u novinama Adria: list udružene privrede Poreštine od kraja 1982. (AD 27. 11. 1982.: 17). Gotovo istodobno i u Uljaniku se pojavljuje poezija na talijanskom radnika koji su članovi Literarne sekcije “Uljanik” (I muretti d'Istria ULJ 15. 4. 1981.: 33).

Regionalno obojeno pjesništvo u časopisima poduzeća očekivana je praksa uredničkih politika i u širem je kontekstu procesa afirmiranja dijalektalne poezije. No, poneki izdvojeni primjeri mogu biti zanimljivi zbog specifičnih značajki. To su primjeri u kojima je iz biografskih podataka vidljivo da autorice ili autori podrijetlom nisu povezani s Istrom, već da je riječ o migrantima, primjerice kod više hibridno-čakavskih pjesama o Istri rođenog Bračanina "traktorista-pjesnika" Ivana Juriševića, kao što su Poslidnji kompanjol i boškarin (GPL 14. 10. 1974.: 15) i gotovo programatska O Istro mila:

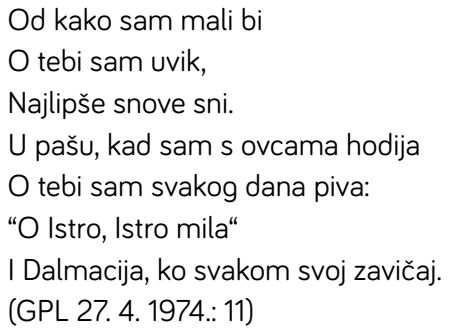

Slični se potezi mogu prepoznati u srodnim primjerima u kojima poezija na književnom jeziku obiluje lokalnim ili regionalnim temama, kao što je Arena u Puli, istarski krajolik, ljudi iz Istre i sl. Autolegitimiranje kroz lokalni idiom i lokalnost kao važna tema otvaraju interpretativni problem većeg opsega, koji bi se mogao svesti na ispreplitanje klasnih i regionalnih identitetskih značajki. Međutim, i takav pristup bio bi problematičan jer ni klasni ni regionalni identiteti nisu uključeni u dominantne značajke izgradnje socijalističkog društva, ne djeluju hegemonijski; to su prvenstveno identitetske razine koje se artikuliraju i dobivaju političku moć u tzv. tranzicijskom razdoblju devedesetih godina.? To moguće regionalno-klasno autolegitimiranje reprodukcijom lokalnih pjesničkih kanonskih matrica uklapalo bi se u one latentne društvene silnice u kasnom socijalizmu koje će se aktivirati njegovim krajem. I dok su regionalne istarske praslike transparentna i vidljiva komponenta, klasno autolegitimiranje $u$ ovom je slučaju moguće iščitati kroz kontekst. Te se pjesme javljaju u medijima koji pripadaju tercijarnom sektoru (turizam) ili industrijama koje imaju stoljetnu tradiciju, a koje u socijalizmu pak primarno imaju vrlo značajnu ulogu u stvaranju, proizvodnji i reprodukciji identiteta lokalnih urbanih sredina, što je slučaj s Labinom i rudnicima (usp. Matošević 2011) kao i s Pulom i Uljanikom. Migrantni karakter tako uključuje

${ }^{7}$ Recentna istraživanja dobro prepoznaju problem latentnog klasnog pitanja u socijalističkoj Jugoslaviji (Škokić i Potkonjak 2016, usp. i Suvin 2014: 103-145). 
prihvaćanje i životne prilagodbe, od pronalaženja dobroga i sigurnog radnog mjesta izvan zavičaja, moguće i u tercijarnim djelatnostima, do napredovanja i socijalne mobilnosti, ali on mora u tom "paketu" sadržavati i prihvaćanje ostalih promjena koje donosi ulazak u modernitet, i to ne isključivo kao socijalistička paradigma novoga društva, već i kao kompleksnija identitetska kategorija. Ona tako podrazumijeva i specifične lokalne procese proizvodnje i (samo)reprezentacije regionalnih identiteta, odnosno njihovo povezivanje s klasnim, srednjeklasnim u prvom redu, a što je moguće prepoznati i u kasnijim i aktualnim (samo)reprezentacijama Istre.

\section{AMBICIOZNI "PATCHWORK" REFLEKSIVNIH I LJUBAVNIH PJESAMA}

Drugoj značajnoj grupi pjesama donekle je izazovnije analitički pristupiti. Riječ je zapravo o dosta heterogenoj skupini pjesama koju se može podvesti pod refleksivnu i ljubavnu liriku. Već se iz takve tipologizacije može iščitati da je namjera tog tipa pjesama reprodukcija, ili barem nasljedovanje i naslanjanje na kanonske tematske matrice poezije, odnosno, da ti opusi računaju s modernistički uokvirenom komunikacijskom namjerom autora i čitateljskim kompetencijama. Pritom valja napomenuti da takvom "povišenom" modelu "seciranja" radničke poezije nije cilj "prokazivati" pjesničke promašaje, naivnost, amaterizam ili diletantizam, već mu je namjera analitički izdvojiti različite slojeve diskursa radničke poezije, koje se potom može interpretirati.

Pjesme koje su svojom tematikom okrenute više refleksivnom polu i problematiziraju pozicije čovjeka ili ljudskosti u svijetu, ili se dotiču smisla postojanja općenito ili umjetnosti u vremenu otuđenja, mogle bi se prepoznati kao pjesnički izrazi proizašli iz ujevićevske ili, češće, cesarićevske tradicije. To u svakom slučaju uključuje spomenute smjerove utjecaja koji se postavljaju kao implicitni kanon proizašao iz široko shvaćenog pojma lektire. Taj pojam lektire je nestabilna pozicija koja se temelji na pretpostavkama jer se ne može potvrditi povijesnim istraživanjima stvarne recepcije hrvatske književnosti među populacijom. ${ }^{8}$ Pretpostavljeni utjecaji u analiziranim pjesmama nisu proizvoljni, već proizlaze iz poznavanja nacionalnog književnog kanona, njegove reprezentacije u povijestima hrvatske književnosti i antologijama te pretpostavke dostupnosti iz mjere "komunikativnosti" s čitateljima. Iz tih se kriterija "komunikativnim klasicima” mogu smatrati Tin Ujević, Dobriša Cesarić, Antun Branko Šimić i drugi emblematični hrvatski pjesnici s njihovim najprepoznatljivijim stihovima. Primjerice, prvi stihovi pjesme Sunce ljubavi glase:

Puče jutro, probudi me mis'o, zraka brža od vjetra i svjetla

Šalje li te možda mliječna staza

\footnotetext{
${ }^{8}$ Moguće polazište svakako je školska lektira, no i to ima svoja ograničenja s obzirom na generacijsku šarolikost. Pregled istraživanja udžbeničkih sadržaja može se naći u uvodu rada "(Re)konstrukcije identiteta u udžbeničkoj produkciji” (Marković 2006: 67, 68) no nijedan od spomenutih radova ne bavi se književnošću.
} 
il mi dođe dok sam mater sis'o?

(NG 15. 2. 1981.: 10)

Motivski inventar već otkriva mnogo u odnosu prema poznatom lektirnom kanonu: motivi svemira mogli bi primjerice podsjećati na Ujevićevu drugu fazu, filozofemičnu, bliskiju Kranjčeviću, s toposom "prodora u visinu" (Šicel 2009: 40) (za što se uvijek navodi primjer pjesme Pobratimstvo lica u svemiru), a početak koji zaziva "vremenske kategorije" tipičan je za Cesarića (Pavličić 2008). Na razini retorike, nizanje retoričkih pitanja može s jedne strane podsjetiti i na usmenoknjiževne epske početke, a s druge strane opet na Cesarića (primjerice u poznatoj pjesmi Poludjela ptica). Komunikativnost stila ponovo se može povezivati s Cesarićevom "jednostavnošću” (Šicel 2009: 46), ali ne i bez prepoznavanja karakteristične "pučke note" ("puče jutro", "mater siso"), u svojevrsnom "snižavanju" registra ili kretanju prema još starijim modelima, primjerice spomenutom Kranjčeviću. Kako te dvije tradicije, refleksivna poezija razdoblja između dva svjetska rata s kanonskim lektirnim matricama te ona pučka, pa i usmenoknjiževna, supostoje u vrlo kratkom početnom odlomku pjesme, može se govoriti o svojevrsnoj heteroglosiji, odnosno spontanoj multidiskurzivnosti stila. Ono što bi se spomenutim i odbačenim "povišenim očištem" moglo čitati kao stilske nesklapnosti, zapravo predstavlja prepoznatljivu značajku toga tipa poezije. Za takve hibridne poetske prakse postoje brojni drugi primjeri, primjerice refleksivna pjesma Knjiga mog života:

Kasno je,

noć

ponovo zatvaram knjigu

i krv se ledi u mojim žilama...

(NG 15. 3. 1981.: 10)

U ovome primjeru frazeologizam "krv se ledi u mojim žilama" na kraju prve strofe pokazuje se kao potpuno nemotiviran u kontekstu teme, emocija i sadržaja čitave pjesme te kao da ne pripada literarnom lektirno-kanonskom, već općem i stereotipnom govornom pretpostavljenom repertoaru "govornoga višeg stila", kojim se "popunjava" ritmička praznina pjesme u nastajanju.

Sklonost "velikim temama" nije iznimka i, gotovo neovisno o autorskim biografijama, mogu se primijetiti spomenute podudarnosti u postupcima oblikovanja pjesama. Primjer ambiciozno postavljene pjesme Čovječuljak, koja tematizira izdvojenost umjetnika, stvaralačkog pojedinca, zapravo je primjer stvaranja pjesme kolažiranjem. Takav nesvjesni postupak pred čitatelja postavlja recepcijski problem u hvatanju ukoštac s logičkim nesklapnostima, stilskim izmjenama registra te, konačno, cjelinom koja proizvodi pjesničke slike koje se doimaju bizarnima ili proturječnima.

Nepozvan je ušao

Sažaljenja vrijedan

Umjetnik i genije

Čovječuljak jedan 
Djelima, kojih je tvorac

neki se ljudi dive

Takvi pijanice, kažu drugi,

ne treba da žive.

(..)

(GPL 12. 9. 1974.: 14)

U pokušaju grupiranja motivskih žarišta ne bi valjalo izostaviti primjedbu kako dio spomenutih pjesama preuzima lirski subjekt koji progovara u liminalnim situacijama ili u graničnim razdobljima dana: noći, sna ili buđenja. Takva je temporalna postava dosta "povoljna" za autora jer time otvara mogućnosti ispisivanja najrazličitijih, pa i fantazmagorijskih sadržaja, a čime se uspješno može proširiti očekivana logika svijeta lirskoga subjekta. Primjeri za to su već spomenute pjesme Sunce ljubavi, Prosjak (GPL 26. 12. 1974.: 20), pa i Lijep je svijet i Novi dan (ULJ 2. 4. 1984: 42), s nabacanim vizijama suvremenog svijeta, kao i pjesma Buđenje iz sna, u kojoj se ponovo ukazuje diskurzivna "nedisciplina" koja proizvodi ponešto bizarne slike.

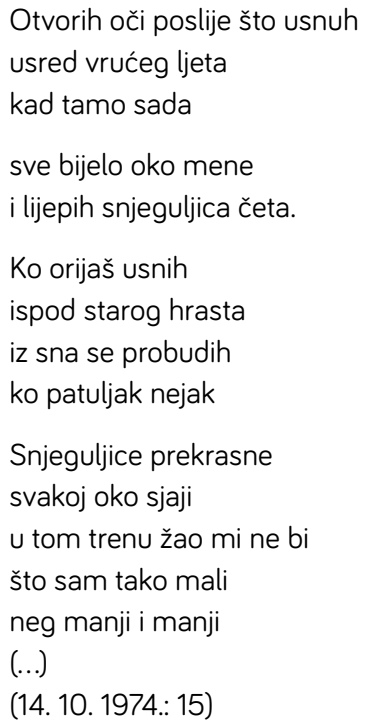

Uz spomenuto temporalno određenje i otvaranje pjesme, a u čemu se, kako je naznačeno, mogu otkrivati između ostalog i cesarićevski utjecaji, i prostor se često povezuje s refleksivnim temama. Krajolik i priroda pritom su očekivani elementi identifikacije lirskoga subjekta koji se odražavaju na ozbiljnu misaonu temu.

Ne diraj nam slobodu

Ja sam travka, mi smo Imamo svoje sunce i svoju livadu.

Ne tražimo od nikoga ništa, ali zapamti - ne diraj nam slobodu!

(GPL 1. 7. 1974.: 10) 
Ljubavna pak poezija u ovom kratkom, specifičnom i ciljanom hrestomatijskom pregledu kao književni podžanr lirike pokazuje najviše stereotipnih, pa i trivijalnih poetskih rješenja, s puno manje prepoznatljivih lektirnih utjecaja, a puno više pučkog, ili čak "šlagerskog" priručnog repertoara. Moguće je da je s obzirom na svojevrsnu ambicioznost refleksivne poezije to i neočekivano - izgleda da se okviri podžanra ljubavne poezije ne postavljaju prema dosezanju visoko estetizirane poezije, već je manira jednostavnosti ili spontane ispovjednosti dominantna. ${ }^{9}$ Zanimljiv je pritom način rodnog kodiranja pjesama: i autorice i autori dijele te registre, no autorice naglašavaju i reproduciraju pasivnu i trpnu poziciju lirskoga subjekta (prva dva primjera), dok se kod autora repertoar kreće od usmenoknjiževnih varijanti nabrajanja dijelova tijela do različitih koketiranja s "frajerštinom":

nije potrebno da kažeš,

koliko sam voljena

nije potrebno da znaš

koliko sam danas žalosna

nije potrebno da znaš

koliko smo nesretni

(...)

(NG 15. 3. 1981.: 10)

Suviše bi bilo ludo da te volim

Suviše bi bilo nisko da te molim

A život je takav da nosi iznenada...

Od njega upoznala sam samo razočaranja

(...)

(NG 15. 3. 1981.: 10)

Ona je bila ko višnjin cvijet

A oči joj bile ko cijeli svijet

(...)

(GPL 9. 1. 1974.: 13)

Rekli su mi da si u disku bila

Da si vajka samo viski pila

Plesala si kako bisno mače

I nosila si uske "rifle" hlače

(...)

(NG 31. 1. 1982.: 10)

Zimsko je hladno veče

kišica je lagana pala

Snežana zovem se reče

dok je na nebu zvijezda pala.

${ }^{9}$ Premda se mogu naći i uspjeliji primjeri ljubavnih pjesama u zbirkama literarnog kluba Uljanik, a i u periodici (npr. Ljubavi vino NG 15. 11. 1980.: 4). 
Ipak sam čuo lavež

u susjednom mi selu

imala je čaroban madež

na dragom za mene čelu.

(..)

(GPL 31. 1. 1973.: 20)

Brojni primjeri refleksivnih i ljubavnih pjesama pokazuju zanimljive podudarnosti. Bilo bi vrlo jednostavno provesti svojevrstan eksperiment kojim bi se moglo pokazati kako se mnogobrojne pjesme toga žanra koje su bile objavljivane u radničkim novinama podudaraju s pjesništvom književnih entuzijasta-amatera i klubaša i u sadašnjosti. Usporedbom s ljubavnim pjesmama objavljivanim u zbirkama Literarne sekcije "Uljanik" također se potvrđuju uobičajeni postupci u stvaranju ljubavnih pjesama.

S te pozicije zapravo iznenađuje iznimno velik interes za ispisivanje refleksivne poezije, kao i raspon i raznolikost tema te hrabro hvatanje ukoštac s velikim temama umjetnosti, stvaralaštva, čovječanstva i smisla ljudskog postojanja. Stilske i logičke nesklapnosti, od frazeologije do stiha, pažljivim čitanjem upućuju na utjecaje i preklapanja lektire, kao i na utjecaje onih praksi koje pisci tih pjesama razumijevaju kao visokoliterarne, zatim višeg stila govora, ali i na one iz različitih oblika usmene i pučke književnosti. Pogled u građu otkriva ipak jednu zanimljivu pojedinost: refleksivne pjesme objavljivane u zbirkama Literarne sekcije brodogradilišta "Uljanik" ipak u većoj mjeri ne pokazuju spomenute elemente stilskih nesklapnosti, ali zato obiluju verbalizmom na granici pretencioznog, što također potvrđuje smjer reprodukcije kanonski literarnog i “visokog” stila.

Može se smatrati, imajući na umu te dinamike individualnog ili literarno-klupskog stvaralaštva, uredničkih odabira (i vjerojatno poticaja) te željene ili ciljane publike radništva, a i reprezentativan uzorak časopisa, kako to pjesništvo ostvaruje specifičan kôd, specifičnu diskurzivnu praksu koja se može razumjeti kao izravna umjetnička praksa radnica i radnika. Logike preklapanja različitih književnih utjecaja, onoga što se u toj dinamici razumije kao visokoestetizirana umjetnička književnost i onoga čime se spontano popunjavaju stihovi, uz stilske nesklapnosti koje u tim tekstovima detektira profesionalni čitatelj, $u$ tom se kontekstu postavljaju kao svojevrsna norma. Ona svjedoči o spomenutoj heteroglosiji, odnosno može se povezati s procesom prepoznatim kao bricoleur, "tehničko majstorstvo" "divlje misli" kakvo opisuje Claude Lévi-Strauss (1966), ali s onim tipom tumačenja brikolerstva, odnosno uza sve one postupke, prilagodbe i procese koje u takvim tipovima pisanja prepoznaje Michel de Certeau u Invenciji svakodnevice (2015), o čemu će biti riječ u zaključku.

To pokazuje dva procesa, odnosno postavlja mogućnost za izricanje svojevrsne teze: te pjesme prikazuju i upućuju na uvjete proizvodnje diskurzivne prakse radničke umjetnosti, kao i njezinu podudarnost s pojedinim elementima samoupravljanja. Ova primjedba zahtijeva pojašnjenje. Ako se pjesme grade, izgrađuju, brikoliraju dostupnim i poznatim kulturnim materijalom, one i upućuju na važnost elemenata i procesa takve proizvodnje, odnosno na pitanje dostupnosti kulturnih elemenata, lektire, pučke, usmene i lokalne knji- 
ževnosti i na poetičku (normativnu) mogućnost njihova supostojanja u radničkoj poeziji. U ovome slučaju upućuju na svojevrsnu demokratičnost u dostupnosti raznorodnih kulturnih elemenata što omogućuje jednakovrijedno upotrebljavanje "visokih" i "niskih" modusa, ili preciznije, "priručno popunjavanje" sadržaja "nižim" ili "višim" umjetničkim modusima.

No, valjalo bi pojasniti i drugu tezu. Samo samoupravljanje, kao demokratična i inkulzivna, specifična, "eksperimentalna" politička strategija društvenog razvoja temeljeno je na ranim artikulacijama marksizma. Budući da, osim različitih Šuvarovih članaka u kojima se uvelike promovira umjetnički amaterizam (Šuvar 1980), nije postojala konzistentna kulturna politika samoupravljanja i u samoupravljanju, postupci nastanka analiziranih pjesama i te diskurzivne prakse zapravo se temelje na svojevrsnoj improvizaciji s dostupnim elementima koji proizlaze iz sustavnih (i ustavnih) načela organizacije novog društva.

I baš kao što se u ekonomskom i društvenom sustavu samoupravljanja "nastojalo obučiti radnika da može čitati i shvatiti vrlo složenu materiju” (Bilandžić 1978: 340), baš kao što je samoupravljanje i samo tek inaugurirani sustav koji se "od pedesete do kraja sedamdesetih godina neprekidno nadopunjavao i 'usavršavao' i nadograđivao" (Bosanac 2015: 96), tako i horizontalno i široko shvaćena kultura i njezina praksa u tom sustavu koji se temelji na participativnosti, horizontalnoj logici, dostupnosti i akciji logički slijedi te značajke. Drugim riječima, u sustavu samoupravljanja, u kontekstu poduzeća i zvanja s kojima "radnici pokazuju velik stupanj identifikacije" i sl. (Archer i Musić 2016: 5), umjetnost koju proizvode sami radnici podudarna je s logikom "savladavanja složene materije" (visoke umjetnosti) kao i s radom u novom, otvorenom sustavu koji se "neprekidno usavršava i nadograđuje", u kojem se problemi rješavaju improvizacijom, u kojem se kalemi, majstorski brikolira, koji se usavršava kroz konkretne akcije, odnosno praksu čiji rezultat ovisi o povjerenju i benevolentnosti dionika. ${ }^{10}$

\section{PJESME IZ POGONA}

Treća grupa radničkih pjesama koje se objavljuju u tvorničkom tisku posebna je jer tematizira na razne načine rad, kontekst obavljanja posla u poduzeću, situacije na radnom mjestu i sl. Taj se korpus pjesama može okvirno razdijeliti u dvije dominantne skupine: kritičko-satiričku poeziju o konkretnim situacijama i kontekstima na radnom mjestu u poduzeću ili tvornici te pjesme koje prikazuju afektivni odnos prema radu, nekom zvanju ili zanimanju. Ta grupa pjesama o radu u tematskoj je distribuciji najslabije zastupljena;

${ }^{10}$ Primjer gotovo etnografske naravi za ove tvrdnje može se naći u istraživanjima samoupravljanja na terenu: "Za prvoga predsjednika radničkoga savjeta izabran je mehaničar-motorist Mate Bonašin, koji je na proslavi desetogodišnjice samoupravljanja u Uljaniku o svojim prvim dojmovima kao predsjednika izjavio da su 'bili u znaku čuđenja, jer nisu imali iskustva, a on kao predsjednik se našao u neobranom grožđu', ali njegova je sreća bila u tome što je poznavao 'problematiku i što su radnici imali povjerenja u njih'” (Stanić 2014: 459). 
nažalost, jer riječ je o doista autentičnim iskustvima rada i vlastitog odnosa prema radu pretočenim u poetske iskaze.

Premda se u ranijim desetljećima poezija posvećena radu i stupovima društva, Titu i Partiji, može sporadično naći u brojevima Raškoga rudara, ${ }^{11}$ za razdoblje koje se istražuje u ovome radu, kronološki promatrano, kritičko-satirički podžanr pjesama o poslu javlja se sredinom šezdesetih godina, i to upravo u Raškome rudaru. Primjer koji slijedi iscrpan je i reprezentativan iz više razloga. Jedan od značajnih elemenata njegove reprezentativnosti upotreba je satiričkog lika, svojevrsne maskote radnog kolektiva, potpuno u skladu s vrlo starom, i ne samo literarnom, tradicijom preuzimanja uloge (maskiranog) glasnogovornika istine, obješenjaka ili dvorske lude. U ovom slučaju zakrabuljeni radnik-rudar-pjesnik, na retuširanoj fotografiji rudara s naglašeno karikaturalnim brcima, preuzima lik koji se zove "Pijuk Šremovski, savjetnik za produktivnost". Pod tim će se likom-maskom, doduše ne posve redovito, u Raškome rudaru godinama objavljivati kritičko-satirička poezija. Pijuk Šremovski pripada tradiciji tipičnih "maskota" socijalističkih poduzeća, kakve su se pojavljivale i u većini ostalih analiziranih tiskovina. Razlika je u tome što su se ti konstruirani likovi "tipičnih radnika" pojavljivali uz žanr karikature (spremačica Anita iz poduzeća "Anita", Konobar Ive iz "Rivijere"), dok je ovdje riječ o rudaru-obješenjaku koji se javlja u poetskom iskazu.

Drugi razlozi reprezentativnosti ovoga primjera otkrivaju se $u$ tome što takav oblik satiričke poezije doista otvara mogućnost prikazivanja vrlo konkretnih situacija u poduzećima, otkrivajući kodiranjem teksta "emocionalne uloge" radnika u različitim procesima samoupravljanja. Kroz opušteni humor oštrije se upućuje na stvarna iskustva radnica i radnika u procesima odlučivanja ili se pak ocrtavaju obrisi svakodnevice koji čine sadržaj razgovora u pogonu ili u uredu. Na djelu je posredna etnografija koja je oblikovana unutar književnog umjetničkog medija.

Konačno, ta je pjesnička igra izvedena vješto, dinamično i s duhovitim dijaloškim izmjenama te je stoga doista dobar primjer uspjele satiričke poezije o problemima samoupravljanja. Pjesmu I dalje hrču navodimo gotovo u cijelosti:

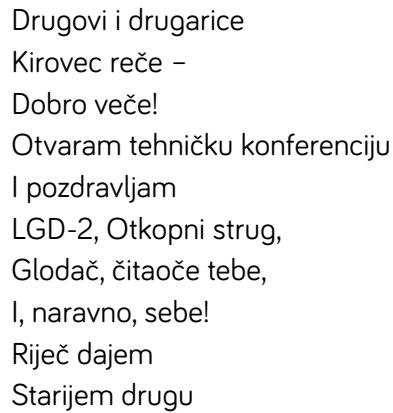

${ }^{11}$ Krugu ideološki nabijenih pjesama može se pripisati i pjesma Dani u Armiji, koja bi pripadala prigodničkom podžanru amaterskih pjesama o vojsci (GPL 31. 1. 1973.: 20) 
Otkopnom strugu.

Drugovi, zabrazdi plug,

Moj je dug

Kao suborcu,

Da odgovorim Kirovcu

Zašto ste i danas u skladištu.

Znam, dok vrijeme kuca

Na vrata operative,

Vi prekovremeno

Pričate viceve.

Žao mi je

Al moram reći glasno

Krivac je nađen

lako kasno,

To je ona sila,

Đavo da je nosi

Koja godinama prkosi,

Ta se zloća zove

Objektivna Teškoća.

Kirovec se nasmijao

Strašno, jako

Motor mu pregorio lako

PGD-1

S autoritetom zastenje:

Drugovi!

To je najbolje rješenje:

Na Objektivnu Teškoću

Dalje ćemo kidisati,

A Kirovca ćemo

Knjigovodstveno otpisati!

(...).

Predlažem da o svemu tome

Prodiskutiramo dogodine

Ni govora!

- Reče Glodač ljut.

- Kirovec ti si lud!

Ja zahtijevam da se utvrdi:

Dokle ćemo

Objektivnu Teškoću

Pratiti

I praznu slamu mlatiti!?

Konferencija je završena

Svjetlo se gasi

Hrču kombajni

Naslagani u masi.

(RR .1. 1. 1965.: 11) 
No diskurzivna praksa toga tipa ima i svoje granice. Relativno autonoman svijet samoupravnih poduzeća otvara i teme koje su uske i specifične, pa ovise o razumijevanju konteksta i specifičnih referenci. To pred čitatelja koji ne poznaje kontekst postavlja iskaze lirskoga subjekta koji se iščitavaju kao hermetični. S jedne strane, bez većih problema može se konstruirati dio konteksta koji obuhvaća situacije na sastancima, nekorisnost rasprava, kao i konkretne osobe rukovodilaca. Jasan je i dio leksika, tehnokratski govor (“Objektivna Teškoća”), profesionalna terminologija (glodač, otkopni strug, motor PGD-1). S druge pak strane, pojedini se elementi izdvajaju iz iskaza i preostaju nejasne pjesničke slike koje neupućen čitatelj može razumjeti jedino kao bizarne (primjerice, što su "kombajni koju hrču naslagani u masi"?).

Drugi primjer, pjesma Rivierski tika taka, objavljena u časopisu Naš glas 1980. godine, može se promatrati kao komplementaran:

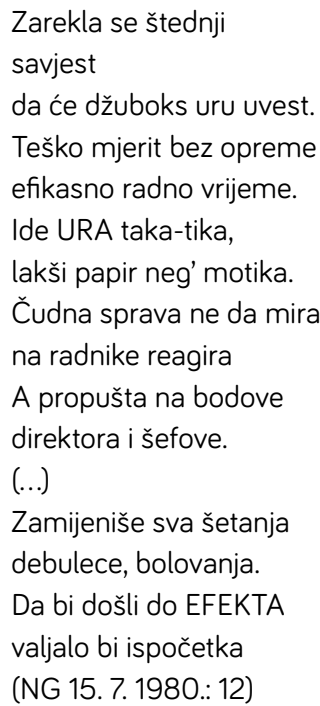

Kao i u prethodnom primjeru, kontekst konkretnih problema na koje se aludira može se $u$ velikoj mjeri rekonstruirati. Satirička pjesma bavi se problemom mjerenja efikasnosti radnog vremena (radnih sati) i nelogičnostima i nepravdama koje, u razdoblju početaka ekonomske krize i uvođenja novog Zakona o radu, takva mjera proizvodi u pogonima na terenu, ali otkriva i oblike radničke samokritike s druge strane. Satirički lik Zuro Sindikalić, ${ }^{12}$ koji "potpisuje" tekst, i naglašavanje administrativne terminologije, neke su od jasnih podudarnosti ovakvog tipa pjesama, uz još jedno prepoznatljivo retoričko sredstvo - personifikaciju, a u slučaju pjesme I dalje hrču, i prozopopoeju. U oba primjera animirani su i predmeti, i to oni iz neposrednog radnog okružja, alati i sl, ali i apstraktni pojmovi koji funkcioniraju u administrativnoj komunikaciji.

${ }^{12}$ Jasna aluzija na ZUR, Zakon o radu, kao i na djelovanje sindikata u toj raspravi. 
Krešimir Bagić i za personifikaciju i za prozopopeju navodi da su retorička sredstva koja se uvelike koriste i u dječjoj književnosti i u oglašivačkoj praksi; personifikacija "stvara značenja koja su bitno odvojena od stvarnih odlika proizvoda" (Bagić 2012: 247). To i jest kritička intencija analiziranoga tipa satirične poezije - naivno dječje personificirati strojeve, alate i predmete iz proizvodnje i animirati ih kao "drugove", subjekte rada na koje se problemi samoupravljanja također odnose, da bi se s druge strane ironijski i travestijski razotkrila "oglašivalačka" nemoć apstraktnih administrativnih pojmova kojima operiraju upravljačke instance u praksi.

Svojevrsni vrhunac objavljivanja satiričke poezije događa se krajem 1987. godine kada se u Porečkom glasniku objavljuje prvi broj satiričkog priloga "La kost" (PG 29. 12. 1987., podlistak), koji postoji i danas. Međutim, tu se ne radi o poeziji radnika, iako se te novine jasno razvijaju iz radničke periodike. U Raškome rudaru Pijuk Šremovski pojavljivat će se godinama, a bilten Uljanik njegovat će od samog početka nove serije izlaženja (1980.) i radničku satiričnu poeziju, a posebno vrlo kvalitetnu karikaturu.

Sadržajno i izvedbeno drugačiji tip poezije koja tematizira rad i radništvo u podjednakoj se mjeri sporadično pojavljuje u građi, a oblikovan je unutar hegemonijskog diskursa o radu i radništvu, odnosno riječ je o pjesmama koje tematiziraju herojstvo rada. Nije slučajno da je nekoliko takvih primjera upravo iz Raškog rudara, jer rudari predstavljaju svojevrsnu metonimiju rada, u strogo organiziranom sistemu, uz elemente opasnosti, "pogibije, hazarda i teškog manualnog rada" (Matošević 2011: 23). Pozicija rudara je, uostalom, metonimijska za poziciju radnika, ne samo u socijalizmu, tako je "kroz njihovu socijalnu perifernost protkana centralnost" (Thesing $\mathrm{u}$ isto):

\section{Iz dubina Podlabina}

Sve se trese, zemlja para

Ugljen vade pet rudara

Mujo, Meho, Alija, Poldi i Đelalija.

Ugljen sreću donosi

Istra se rudarima ponosi

Svuda mrak oko nas

Crno zlato zemlji spas.

Nek se šire hodnici

Nek pucaju mine

Nek vrte borhameri

Nek stresaju rine.

Pikolator sitno brekće

Ajzenbajz ga potkopava

Kad ga ima na otkopu

Krcati je želja prava.

Hej, rudari smo mi

Sretno drugari!

(RR 30. 6. 1981.: 7) 


\author{
Rudaru \\ Žuljeva amo garavi stvore \\ otvrdnute radom u rijeci znoja \\ gorka li je i slana kora hljeba \\ što je mjesi (!) ta ruka tvoja. \\ Svakoga dana i svake noći \\ utrobu zemlje ruješ i slažeš \\ i ne znaš da li ćeš stići \\ sutra svima SRETNO da kažeš. \\ Ličiš na nekog golemog crva \\ ne ljuti se zato drugaru stari \\ ti ruješ da bi nam bolje bilo \\ ko' što su činili naši stari. \\ (RR 1.3. 1982.: 8)
}

Ovi i slični oblici pjesničkoga iskaza pojavljuju se još od četrdesetih godina u radničkim novinama (npr. Pismo Drugu Titu uoči Kongresa, 1. 5. 1949.: 5, Prvomajska RR 1. 5. 1949.: 9, Istarski partizan RR 15. 5. 1949.: 3 itd.), manje poznatih autora, kao i pjesnika poput Draga Gervaisa, međutim navedena su dva primjera iz 1981. i 1982. godine. Pjesme koje pišu sami rudari o rudniku i o svom poslu, vrlo podudarnih kompozicija, mogu se naći od šezdesetih godina, poput pjesme kopača Save Kneževića: ${ }^{13}$

Tko to silna brda trese

Tko im nikad ne da mira?

To radi garava četa

Jovančeta brigadira!

(...)

Brekće, huči motor vreo,

Sat brzo vrijeme kuje

Lete s čela graške znoja

Dok četa plan ostvaruje.

(RR 25. 8. 1964.: 11)

Ti tipovi pjesama sasvim su uobičajeni primjeri reprodukcije bilo kojeg oblika hegemonijskog idejnog repertoara $u$ bilo kojem vremenu. Dio motiva i frazema koristi horizont svijeta industrijskog rada i strojeve kao slike, a u starijim primjerima radna terminologija, čak i ona administrativna, nalazi svoje mjesto. Očekivano, u njima lirski subjekt progovara iz hegemonijskog diskursa emfaze rada, no na razini rime, ostalih frazema i ritma koketiraju s narodnim i pučkim iskazima, s gotovo naivnom umjetnošću. U svim primjerima tih pjesama rimovanje je obavezan retorički postupak. Nekoliko elemenata ipak privlači analitičku pozornost. U pjesmi Iz dubina Podlabina to je spominjanje petorice rudara, čija imena zazivaju prepoznavanje njihovog podrijetla, što nije slučajno: aluzija je to i na Labinsku republiku kao "anacionalnu, internacionalnu i heterogenu" (Matošević 2011: 56) borbu za radnička

${ }^{13}$ Primjera ima još, npr. Proizvodnja (RR 15. 7. 1965.:.11), Rudar (RR 1. 5. 1967:: 2), a mogu se naći i u Uljaniku, npr. Brodograditelji (ULJ 15. 4. 1981.: 33). 
prava, ali i politička aluzija na potrebu jedinstva u vremenu krize, koja počinje osamdesetih, a kulminira, među ostalim, upravo i poznatim nacionalno motiviranim štrajkom kosovskih rudara u Trepči 1989., čime je smisao pjesme povijesno kontekstualiziran i aktualan.

To što postoje primjeri pjesama nastalih i objavljenih i u 1980-im godinama, svjedoči i o rezistentnosti takvog tipa diskursa. Ta dugovječnost, premda nedvojbeno podržavana od struktura moći, pokazuje da se radi o obliku prihvatljivog i prihvaćenog, novog motiva rada koji je uklopljen u pučku ili strukturu naivne umjetnosti. Uzmemo li u obzir imitaciju i reprodukciju hegemonijskog umjetničkog diskursa za "ostvarenje jezične postave" s potrebom za ekspresijom "životnog totaliteta” (Bošković Stulli i Zečević 1978: 360), u koji sada kao nova sastavnica totaliteta ulazi i rad u pogonu, možemo potvrditi domaće teze o "pučkom književnom fenomenu" kao onome koji je "tranzitno područje između usmene u umjetničke književnosti" (isto: 377). Ti bi poetski iskazi svojom dugovječnosti odgovarali, da se poslužimo Andréom Jollesom, "duhovnoj zaokupljenosti" kakvu imaju legende exemplum ili imitacija (Jolles 2000: 57), odnosno književno uobličeni primjeri koje valja slijediti. Ideološko je $u$ analiziranim primjerima neodvojivo povezano s usmenim i pučkim pri čemu se novi motivi i teme rada jednostavno uklapaju u već postojeće matrice usmenosti. Valja imati na umu da u tom trenutku i jest bila riječ o "novome" svijetu i novome horizontu radnika - pjesnika, koji upravo u tim desetljećima žive industrijsku revoluciju.

Pjesma Rudaru posve nenamjerno otkriva značajku koja se spominjala i kod refleksivnih, ljubavnih pjesama - nesklapnu ili bizarnu pjesničku sliku ("ličiš na nekog golemog crva") te bi uz to, i zbog niza drugih, očekivanih značajki, bilo uputno i pjesme o radu i radnicima također promatrati i kao oblike "varijacija kanona", s nadodanom reprodukcijom novih ideoloških sadržaja. Ovdje je, međutim, smjer suprotan, "tradicijski kanon" je norma na koju se nakalemljuje nov sadržaj.

Nadalje, prema brojnim svojim karakteristikama, tematici, teksturi i autorstvu, taj bi tip pjesama najbliže odgovarao "deklarativnim populističkim zahtjevima nove kulture i književnosti" (Kolanović 2011: 65) kakvu je zagovarao kratkotrajan i napušten model socijalističkog realizma. Koncepcija "umjetnosti proletarijata" (Šinko u isto: 64) odgovarala bi kao odrednica čitavome korpusu, međutim, u pjesmama s temom rada prepoznatljiva je reprodukcija dominantnog ideološkog diskursa, dok se u svim ostalim tipovima mogu iščitati različite mjere pregovaranja s njime.

\section{ZAKLJUČAK}

Kronološko analitičko praćenje radničke poezije ovisi, dakako, i o vremenu pokretanja pojedinih časopisa. Ukupno promatrano, poezija radnika i radnica može se u proučavanom korpusu pratiti od početka 1960 -ih, odnosno nakon što 1959. godine Raški rudar prestaje neredovito izlaziti $u$ šapirografnom izdanju te unaprjeđuje i profesionalizira koncepciju novina, te potom krajem 1960-ih, kada počinju izlaziti tiskovine turističkih poduzeća. 
Od 1960-ih do kraja socijalističkog razdoblja mogu se pratiti pjesme s tematikom rada i satiričke pjesme. Od 1970-ih u turističkim časopisima objavljuju se i ljubavne i refleksivne pjesme, a vezano uz proizvodnju regionalnog identiteta, i pjesme na čakavskom. Svi ti tipovi poetskih izričaja moći će se naći i potvrđivati i u izdanjima Brodogradilišta "Uljanik", od 1980., pri čemu je čakavska lirika prisutnija u biltenu Uljanik, a ostali modeli u zbirkama Literarne sekcije.

Pjesme koje su u nekoliko posljednjih desetljeća samoupravljanja pisali radnici za radnike, koje su se objavljivale u medijima namijenjenim radnicima u poduzećima, pokazuju u svim svojim oblicima sličan model "varijacija kanona", s iznimkom kritičko-satiričkih pjesama, koje ionako ovise o kontekstualiziranju, a u provedbi pokazuju samosvojne kvalitete. Bilo da je riječ o modeliranju lokalnog čakavskog dijalektalnog izričaja, u čemu zapravo nailazimo i na afirmirane lokalne autore, o pokušajima slijeđenja lektirnih utjecaja ili visokoumjetničkog diskursa, ili o modelima "tradicijskog kanona", može se u pisanju radnika prepoznati implicitna skripturalna norma, pismo, pisanje koje se određuje kao primjereno, već spomenuti kanon čijom se nadogradnjom i varijacijama ostvaruje pojedinačni stvaralački čin.

Model kojim bi se zaključno moglo interpretirati analiziranu građu, čini se, krije se upravo u složenosti odnosa glasa, puka i usmenosti te modernizma, pisanja, skripture i hegemonijske kanonske pisanosti. Taj je složeni odnos najopsežnije razradio Michel de Certeau u Invenciji svakodnevice. On propitkuje spomenute odnose koristeći pojam "skripturalne ekonomije": pisanje je "moderna mitska praksa" a "napredak je skripturalnoga tipa" (de Certaeu 2002: 204). De Certeau pisanje, dakle, postavlja upravo kao ključnu odrednicu modernosti, što odgovara viziji projekata socijalizma i samoupravljanja, a i uobičajenoj predodžbi polja umjetnosti i književnosti. Međutim, u toj logici de Certeau inzistira na pokušaju dekonstrukcije strogih granica, koje se zapravo političkim potezima postavljaju u samoj modernosti, konstruirajući predodžbu Drugoga, alternoga, pučkoga, "nižega" ili "slaboga", "nejakoga" (isto: 40) u modernitetu. Njega zanimaju svakodnevica, "pučka kultura", "umijeće činjenja”, "pučki postupci", prilagodbe, improvizacije, trikovi, pregovaranja alteriteta s dominantnom "modernom mitskom praksom". Usmenost i tradicijske i popularne kulture "Drugih" ulaze tako u kompleksan, istovremeno i pasivan i proizvodan, odnos s modernosti, baš kao što je to slučaj s analiziranom građom:

Laboratorij pisanja ima "stratešku" ulogu: bilo da se obavijest preuzeta iz tradicije ili izvana u njoj nađe prikupljena, razvrstana, uklopljena u sustav i na taj način preobražena, bilo da razrađena pravila i obrasci na tom izdvojenom mjestu omoguće djelovanje na okolinu i njezinu preobrazbu. Otok stranice mjesto je prijelaza na kojemu se odvija industrijski obrat: što u nj ulazi je nešto "zaprimljeno", što izlazi je "proizvod". Stvari koje u nj ulaze pokazatelji su "pasivnosti" subjekta u odnosu na tradiciju: one koje izlaze, obilježja su njegove moći da proizvodi predmete. (isto: 205)

U svim primjedbama u ovome radu, od "varijacija kanona" do stilskih nesklapnosti u brikoliranju i heteroglosije, mogu se prepoznati upravo te prakse prilagodbe kulture (radne 
svakodnevice) koja ne pripada posvećenom snažnijem polu proizašlom iz modernosti, već različitim "pučkim" postupcima ulazi u dinamičan i proizvodan pregovarački odnos s njom. Doista, de Certeau zaključuje da se "cijela takozvana 'pučka' književnost različito predočuje: ona se temeljno određuje kao “umijeće činjenja'” (isto: 35).

Ako se, dakle, samoupravna kultura ili kultura u samoupravljanju u velikoj mjeri podudara s prijeporima nastalim u zapadnom modernitetu, kao posljedici kolonijalnih i klasno rastačućih procesa koje napominje de Certeau, onda takva podudarnost, a imajući na umu i podudarnost o razumijevanju kulture kao svakodnevice, u slučaju kulturnih praksi umanjuje "izvornost", autentičnost, ili čak "eksperiment" samoupravnih procesa u kulturi. To potvrđuje spomenute teze da je u okviru samoupravljanja kulturna politika dobrim dijelom "prepuštena" inerciji ili momentu kretanja sustava. Potvrđuje također i spomenuti problem artikulacije kulture u marksizmu kao i, konkretnije, teze Reane Senjković o tome da je takav koncept kulture donio malo novih ideja.

Poezija koja se objavljuje $u$ analiziranim tiskovinama katkad je kontekstualizirana biografijama autora. Rijetko je to slučaj u novinama Naš glas ili Glasnik Plave Lagune, a moguće je pronaći i nekoliko podataka u biltenu Uljanik, no publikacije Literarnog kluba brodogradilišta pružaju nešto više podataka o autorima. Već se jednostavnim pogledom na biografije može razaznati da su ideju pisanja poezije u radničkom literarnom klubu prihvatili radnici i radnice različitih profila, različite razine obrazovanja, pa i različitog podrijetla. Određeno "klasno pozicioniranje" bilo bi moguće primijetiti vezano uz antologijske autore poput Janka Crljenice ili Denisa Kontošića (usp. Biletić 1997), tehnički visokoobrazovanih i na rukovodećim pozicijama (ULJ 8. 3. 1990.: 29), no bilo bi ipak preuranjeno za stvaranje zaključaka na toj osnovi, posebno imajući u vidu i antologijski protuprimjer brodskog cjevara Dinka Š. Kalca. Također, kada su naznačene u kratkim intervjuima, motivacije autorica i autora za bavljenje pisanjem pokazuju se kao osobne i ne otkrivaju mnogo (npr. "pišem za svoju dušu", GPL 12. 9. 1974.: 14, "pišem da bih si olakšala dušu” GPL 26. 12. 1974.: 20, "nadahnut vedrinom Istranina” ULJ 8. 3. 1990.: 29).

Uopće, trebalo bi primijetiti da je složeno pitanje u kojoj se mjeri umjetničko stvaralaštvo radnika, zapravo rijetka praksa korištenja slobodnog vremena unutar sustava rada (premda radnici sami svoje pisanje opisuju kao rad, bavljenje, činjenje, praksu), može povezati sa stvarnim ekonomskim, političkim i sistemskim učincima. Nadalje, ta praksa pisanja je fakultativna, pomalo ekskluzivna i probrana, s jasnim "slijepim pjegama" prema popularnoj, narodnoj i potrošačkoj kulturi te stoga i ne govori puno o stvarnoj življenoj kulturi onih koji su je stvarali. Uz poneke prepoznatljive smjerove kretanja prema pozicijama etablirane ili “visoke kulture”, njezin je okvir većinom sveden na socijalističko poduzeće.

Specifičnosti te poezije mogu se potvrditi, dakle, kroz procese koji su podudarni samoupravljanju kao "nedorađenoj" i izvornoj politici koja se dinamično artikulira kroz kretanja iz centara moći, kapilarno se spuštajući do pojedinačnih radničkih kolektiva i samih radnika da bi povratno proizvodila prakse koje se mogu kretati prema centrima moći. Elementi koji su analizirani u ovome radu, od strukture medijskog proizvoda, distribucije 
participacije, preko specifičnih stilskih i motivsko-tematskih postupaka do procesa pregovaranja s otvorenošću samokreiranja proizvodnje poezije u interferencijama s implicitnim kanonom, pokazuju procese podudarne ideji samoupravljanja. Uz etnografske primjere (usp. Stanić 2014), mišljenje Darka Suvina u recentnoj temeljitoj ekonomskoj i filozofskoj analizi samoupravljanja (Suvin 2014) odgovaralo bi također zaključcima koji proizlaze iz analiza radničke poezije, te se može čitati i u tom registru: "Moj bi stav bio da je postojala neriješena napetost između hijerarhijske i horizontalne integracije, vrlo različita od mjesta do mjesta, koja je obećavala ukoliko se razvijala u smjeru stvarnog sudjelovanja radnika iz pogona u donošenju odluka" (isto: 323). U tom smislu "kultura u samoupravljanju" u svojoj poetskoj praksi doista znači otvaranje vrlo širokog i institucionalno podržavanog prostora pregovaranja i integracije raznorodnih vrijednosno obilježenih elemenata. Brikolerska meštrija, "umijeće činjenja", tako je kretanjem sustava jednako prepoznatljiva i u poeziji i u društvenoj baznoj praksi radničkog samoupravljanja u pogonima. Pritom recepcija obiju praksi ovisi o (dobroj) namjeri.

\section{IZVORI S KRATICAMA}

Adria: list udružene privrede Poreštine, Poreč (1982.) - AD.

Anita: list hotelsko turističkog poduzeća "Anita”, Vrsar (1970. - 1982.) - AN.

Glasnik Plave lagune: list Plave lagune Poreč, Poreč (1970. - 1982.) - GPL.

Naš glas: glasilo poduzeća Rivijera Poreč, Poreč (1968. - 1982.) - NG.

Porečki glasnik: glasilo SSRN i udruženog rada Poreštine, Poreč (1983. - 1994.) - PG.

Raški rudar: glasilo Istarskih ugljenokopa “Tupljak”, Labin (1947. - 1993.) - RR.

Uljanik: mjesečnik SOUR-a Brodograđevna industrija, Uljanik, Pula (1980. - 1991) - ULJ.

Grupa autora. 1984. Zbirka poezije Literarne sekcije KUD-a “Uljanik” (2). Pula: Uljanik.

Grupa autora. 1986. Zbirka poezije Literarne sekcije KUD-a “Uljanik" (4). Pula: Uljanik.

\section{NAVEDENA LITERATURA}

Archer, Rory i Goran Musić. 2016. "Approaching the Socialist Factory and Its Workforce. Considerations from Fieldwork in (Former) Yugoslavia”. Labor History, 1-23.

Bagić, Krešimir. 2012. Rječnik stilskih figura. Zagreb: Školska knjiga.

Bilandžić, Dušan. 1978. Društveni razvoj socijalističke Jugoslavije. Zagreb: Naklada CCD.

Biletić, Boris. 1997. I ča i što i kaj. Iz suvremene hrvatskoistarske lirike. Pula: Sveučilišna knjižnica u Puli, Istarski ogranak Društva hrvatskih književnika.

Biti, Vladimir. 2000. Pojmovnik suvremene književne i kulturne teorije. Zagreb: Matica hrvatska.

Bonfiglioli, Chiara. 2015. "Gendered Citizenship in the Global European Periphery. Textile Workers in Post-Yugoslav States”. Women's Studies International Forum 49: 57-65. [https://doi.org/10.1016/j. wsif.2014.07.004] 
Bosanac, Gordana. 2015. Ime utopije. Jugoslavensko samoupravljanje kao izigrani projekt emancipacije. Opatija: Shura publikacije.

Bošković-Stulli, Maja i Divna Zečević. 1978. Usmena i pučka književnost. Zagreb: Liber, Mladost.

Bourdieu, Pierre. 2011. Distinkcija. Društvena kritika suđenja. Zagreb: Antibarbarus.

Compagnon, Antoine. 2007. Demon teorije. Zagreb: AGM.

Cvek, Sven, Snježana Ivčić i Jasna Račić. 2015. "Jugoslavensko radništvo u tranziciji. 'Borovo' 1989". Politička misao 52/2: 7-34.

de Certeau, Michel. 2002. Invencija svakodnevice. Zagreb: Naklada MD.

Čolović, Ivan. 1985. Divlja književnost. Beograd: Nolit.

Doknić, Branka. 2013. Kulturna politika Jugoslavije 1946-1963. Beograd: Službeni glasnik.

Duda, Dean. 2002. Kulturalni studiji. Ishodišta i problemi. Zagreb: AGM.

Enzensberger, Hans Magnus. 1986. “Constituents of a Theory of the Media”. U Video Culture. John Hanhardt, ur. Layton: Peregrine Smith Books, Visual Studies Workshop, 62-84.

Fine, Gary Alan. 2004. Everyday Genius. Self-taught Art and the Culture of Authenticity. Chicago: University of Chicago. [https://doi.org/10.7208/chicago/9780226249605.001.0001]

Hobsbawm, Eric. 1983. The Invention of Tradition. Cambridge: Cambridge University Press.

Horvat, Branko. 1983. Politička ekonomija socijalizma. Zagreb: Globus.

Jolles, André. 2000. Jednostavni oblici. Zagreb: Matica hrvatska.

Kardelj, Edvard. 1977. Samoupravljanje u Jugoslaviji 1950-1976. Beograd: Privredni pregled.

Komelj, Miklavž. 2009. Kako misliti partizansko umetnost? Ljubljana: Založba / ${ }^{\star} \mathrm{cf}$.

Kolanović, Maša. 2011. Udarnik! Buntovnik? Potrošač... Popularna kultura i hrvatski roman od socijalizma do tranzicije. Zagreb: Naklada Ljevak.

Koroman, Boris. 2016 "Radnički tisak i problemi koncepta samoupravljanja u kulturi u Hrvatskoj 70-ih i 80-ih godina 20. st.". Acta Histriae 34/3: 615-638.

Lavelle, John F. 2012. Blue Collar, Theoretically. A Post-marxist Approach to Working Class Literature. Jefferson, London: McFarland \& Company.

Lévy Strauss, Claude. 1966. Divlja misao. Beograd: Nolit.

Marković, Jelena. 2006. “(Re)konstrukcije identiteta u udžbeničkoj produkciji. Analiza sadržaja udžbenika za prva četiri razreda osnovne škole od 1945. do danas". Narodna umjetnost 43/2: 67-94.

Matošević, Andrea. 2011. Pod zemljom. Antropologija rudarenja u Labinštini u XX. stoljeću. Zagreb, Pula: Institut za etnologiju i folkloristiku, Sveučilište Jurja Dobrile u Puli.

Pavličić, Pavao. 2008. “Kad počinju Cesarićeve pjesme?”. Dani hvarskog kazališta 34: 59-76.

Senjković, Reana. 2008. Izgubljeno u prijenosu. Pop iskustvo soc kulture. Zagreb: Institut za etnologiju i folkloristiku.

Solar, Milivoj. 2006. Rječnik književnog nazivlja. Zagreb: Golden marketing.

Stanić, lgor. 2014. "Što pokazuje praksa? Primjer funkcioniranja samoupravljanja u brodogradilištu Uljanik 1961. - 1968. godine". Časopis za suvremenu povijest 3/46: 453-474.

Suvin, Darko. 2014. Samo jednom se ljubi. Radiografija SFR Jugoslavije. Beograd: Rosa Luxemburg Stiftung.

Škokić, Tea i Sanja Potkonjak. “'Working Class Gone to Heaven'. From Working Class to Middle Class and Back". Narodna umjetnost 53/1: 117-132.

Šicel, Miroslav. 2009. Povijest hrvatske književnosti, 5. Razdoblje sintetičkog realizma (1928-1941). Zagreb: Naklada Ljevak. 
Šuvar, Stipe. 1980. Politika i kultura. Zagreb: Globus.

Williams, Raymond. 1985. "Culture is Ordinary". U On Culture and Society. Jim Mc Guigan i Raymond Williams. Los Angeles, London: Sage.

Willis, Paul. 2006. "Kultura tvorničkoga pogona, muškost i oblik plaće”. U Politika teorije. Zbornik rasprava iz kulturalnih studija. Dean Duda, ur. Zagreb: Disput, 141-156.

\section{LITERARY PRODUCTION OF WORKERS IN SELF-MANAGEMENT: REPRODUCTION OF THE LITERARY CANON, LITERATURE AND EVERYDAY PRACTICES}

This article presents an analysis of some one hundred poems written by workers and published in workplace periodicals between 1947 and 1990. The workplace periodicals considered in the paper were published in the region of Istria in Croatia. Taking Istrian periodicals allowed examining different sectors of the economy - the mining industry, shipbuilding industry, and tourism - in performing this regional case study. The literary material considered in the paper appeared in the historical context of the Yugoslav selfmanagement system with vaguely defined cultural policies. The paper focuses on the relationship between culture and self-management as a political and theoretical idea, and the way in which artistic amateur practices appears in this context. The analysis starts with grouping the poems and finding common themes, motifs and rhetorical structure. This forms the foundation for cultural analyses and interpretations. The interpretations start with poems written in the local čakavian dialect, followed by reflective and love poetry, and ending with poems with dealing with the topic of work and the workplace. Based on the theoretical framework developed by Michel de Certeau, the analysis shows that there is a connection between economic, political and everyday self-management practices on the one hand and the production of a highly varied and heteroglossic poetry written by workers on the other.

Keywords: self-management, art created by workers, poetry created by workers 